\title{
OCCURRENCE OF HYPERBILIRUBINAEMIA IN NEW-BORN BABIES AND ITS RELATION TO MATERNAL FACTORS
}

\author{
Debasis Kr. Samanta1, Swesh Chandra², Shubhra Datta3 ${ }^{3}$ Shyamali Datta ${ }^{4}$ \\ ${ }^{1}$ Senior Resident, Department of Paediatrics, SSKM Hospital, Kolkata. \\ ${ }^{2}$ Senior Resident, Department of Paediatrics, Dr. BSA Hospital, Rohini, Delhi. \\ ${ }^{3}$ Senior Resident, Department of General Surgery, SSKM Hospital, Kolkata. \\ ${ }^{4}$ Associate Professor, Department of Paediatrics, MGM Medical College and LSK Hospital, Kishanganj, Bihar.
}

\section{BACKGROUND}

ABSTRACT

Neonatal Hyperbilirubinaemia (NNH) is a significant cause of neonatal morbidity and prolongation of hospital stay, which in turn increases the chances of sepsis and mortality in the new-born period. Identification of the risk factors and timely detection and optimal management of $\mathrm{NNH}$ are thus crucial to prevent brain damage and subsequent neuromotor retardation due to bilirubin encephalopathy.

\section{MATERIALS AND METHODS}

This prospective study was carried out in M. G. M. Medical College and L. S. K. Hospital, Kishanganj (Bihar); 700 new-born babies delivered between December 2011 and June 2013, were included in the study. New-born babies who developed hyperbilirubinaemia were considered as 'CASE' and new-born babies with the same maternal factors, who did not develop hyperbilirubinaemia were considered as 'CONTROL;' 100 cases and 600 control patients were studied. All parameters were taken during the hospital stay of the mother and baby, which was 5 - 7 days born (term and healthy babies are included only). Peripheral venous blood sample was drawn at the first appearance of significant clinical icterus according to Kramer's criteria. Serum bilirubin estimation was done in the Biochemistry Department of this hospital.

\section{RESULTS}

Incidence of NNH is $16.67 \%$ of all live-born babies in our hospital, which has an annual delivery rate of approx. 4000 . We have noted that the incidence of jaundice of the cases of OA incompatibility, the percentage of babies who develop hyperbilirubinaemia is $20 \%$. Of the cases of $\mathrm{OB}$ incompatibility, the percentage of babies who develop hyperbilirubinaemia is $23 \%$. If we take ABO incompatibility together, the incidence of hyperbilirubinaemia is $7.17 \%$. In our series, $\mathrm{Rh}$ incompatibility was $4.16 \%$ and can be reduced by religious use of anti-D gamma globulin (Rho GAM) in all deliveries and miscarriages in the Rh negative mothers.

\section{CONCLUSION}

Blood group incompatibility as a whole is associated with increased incidence of hyperbilirubinaemia. ABO incompatibility does not have a significant impact on the incidence of NNH. Rh incompatibility is associated with increased incidence of neonatal hyperbilirubinaemia. Judicious use of inj. Anti-D immunoglobulins should be emphasised in suspected cases of Rh incompatibility to prevent $\mathrm{NNH}$ and its neurological effects. Early detection of maternal risk factors also should be done to prevent the development of $\mathrm{NNH}$ and kernicterus.

\section{KEYWORDS}

Neonatal Hyperbilirubinaemia, Kernicterus, Maternal Factors, ABO and Rh Incompatibility, Anti-D Immunoglobulins, Encephalopathy.

HOW TO CITE THIS ARTICLE: Samanta DK, Chandra S, Datta S, et al. Occurrence of hyperbilirubinaemia in new-born babies and its relation to maternal factors. J. Evolution Med. Dent. Sci. 2016;5(98):7162-7165, D0I: 10. 14260/jemds/2016/1621

\section{BACKGROUND}

Neonatal jaundice is the commonest abnormal physical finding during the first week of life. Neonatal Hyperbilirubinaemia $(\mathrm{NNH})$ is a significant cause of neonatal morbidity and prolongation of hospital stay, which in turn increases the chances of sepsis and mortality in the new-born period.

Financial or Other, Competing Interest: None.

Submission 01-11-2016, Peer Review 24-11-2016,

Acceptance 01-12-2016, Published 07-12-2016.

Corresponding Author:

Dr. Debasis Kr. Samanta,

S/o. Sanjay Kr. Samanta,

Vill+P.O.-Devlia, PS-Kolaghat,

Purba Medinipur-721154,

West Bengal.

E-mail:dr.debasissamanta@gmail.com

DOI: 10. 14260/jemds/2016/1621

(c) $\underset{\mathrm{BY}}{\mathrm{NC}} \mathrm{ND}$
Jaundice is the commonest abnormal physical finding during the first week of life. Hyperbilirubinaemia is recognised as clinical jaundice in approximately $20 \%-50 \%$ of full-term and $80 \%$ of preterm neonates. ${ }^{1}$ Identification of the risk factors and timely detection and optimal management of $\mathrm{NNH}$ are thus crucial to prevent brain damage and subsequent neuromotor retardation due to bilirubin encephalopathy.

Even following detailed laboratory investigations, paediatricians are often faced with a significant number of neonates with hyperbilirubinaemia where exact cause remains unidentified.

Therefore, at this day and age when early hospital discharge should be the norm, it is important to determine some factors which could be utilised to predict the occurrence of jaundice in otherwise healthy new-born. 
Aims and Objectives

1. Incidence of neonatal hyperbilirubinaemia within the period of study.

2. Correlation of hyperbilirubinaemia with various maternal factors.

- Mode of delivery.

- Age of mother.

- Blood group incompatibilities.

- Use of OCP.

- Maternal disease.

- Type of feeding.

- Nutritional status of mother.

\section{MATERIALS AND METHODS}

The study was carried out in M. G. M. Medical College and L. S. K. Hospital, Kishanganj (Bihar); 700 new-born babies delivered between December 2011 and June 2013, were included in the study.

New-born babies who developed hyperbilirubinaemia were considered as 'CASE' and new-born babies with the same maternal factors, who did not develop hyperbilirubinaemia were considered as 'CONTROL;' 100 cases and 600 control patients were studied.

This was a prospective study. All parameters were taken during the hospital stay of the mother and baby, which was 57 days born (term and healthy babies are included only). Data was collected according to the proforma. All babies were examined in naked condition in natural day light for appearance of icterus. Peripheral venous blood sample was drawn at the first appearance of significant clinical icterus according to Kramer's criteria. ${ }^{2}$ (In new-born infants, progressive hyperbilirubinaemia is accompanied by a caudal advancement of dermal icterus which begins at the face and proceeds to the trunk, the extremities and finally to the palms and soles).

Conventionally, Neonatal Hyperbilirubinaemia (NNH) has been defined as bilirubin levels greater than $12.9 \mathrm{mg} / \mathrm{dL}$ in preterm babies and $15 \mathrm{mg} / \mathrm{dL}$ in term babies. These definitions are based on the data from the National Collaborative Perinatal Project data (CCP) conducted in the US from 1955 - 1961.3 Total serum bilirubin value of more than $12.9 \mathrm{mg} / \mathrm{dL}^{2}$ at any time during first week of life was considered as hyperbilirubinaemia in the present study. ${ }^{4}$

The statistical constants have been calculated by standard methods. The tests of significance have been done by using chi square test.

Appropriate treatment in the form of phototherapy or exchange transfusion was given as per standard guidelines ${ }^{5}$ and protocols followed by the hospital.

Serum bilirubin estimation was done in the Biochemistry Department of this hospital. The method applied was Jendrassik and Grof technique. To identify aetiological spectrum, several investigations of baby were done: viz. ABO, Rh typing, DCT, reticulocyte count, haemoglobin estimation, peripheral smear, haematocrit, G-6 PD screening.

\section{RESULTS}

\begin{tabular}{|c|c|c|}
\hline $\begin{array}{c}\text { Mode of } \\
\text { Delivery }\end{array}$ & $\begin{array}{c}\text { Babies without } \\
\text { Hyperbilirubinaemia } \\
(\mathbf{n}=\mathbf{6 0 0})\end{array}$ & $\begin{array}{c}\text { Babies with } \\
\text { Hyperbilirubinaemia } \\
\text { (n= 100) }\end{array}$ \\
\hline $\begin{array}{c}\text { Caesarean } \\
\text { section }\end{array}$ & $193(32.17 \%)$ & $24(24.00 \%)$ \\
\hline Instrumental & $61(10.17 \%)$ & $16(16.00 \%)$ \\
\hline $\begin{array}{c}\text { Normal } \\
\text { Vaginal } \\
\text { delivery }\end{array}$ & $346(57.66 \%)$ & $60(60.00 \%)$ \\
\hline \multicolumn{2}{|c|}{ Table 1. Occurrence of Hyperbilirubinaemia } \\
in Relation to Mode of Delivery
\end{tabular}

\begin{tabular}{|c|c|c|}
\hline $\begin{array}{c}\text { Age } \\
\text { (yrs.) }\end{array}$ & $\begin{array}{c}\text { Babies without } \\
\text { Hyperbilirubinaemia } \\
(\mathbf{n}=\mathbf{6 0 0 )}\end{array}$ & $\begin{array}{c}\text { Babies with } \\
\text { Hyperbilirubinaemia } \\
\text { (n= 100) }\end{array}$ \\
\hline$<20$ & $57(9.50 \%)$ & $10(10.00 \%)$ \\
\hline $20-30$ & $367(61.17 \%)$ & $62(62.00 \%)$ \\
\hline$>30$ & $176(29.33 \%)$ & $28(28.00 \%)$ \\
\hline \multicolumn{2}{|c|}{ Table 2. Occurrence of Hyperbilirubinaemia } \\
in Relation to Age of Mother
\end{tabular}

\begin{tabular}{|c|c|c|}
\hline $\begin{array}{c}\text { Blood Group } \\
\text { Incompatibility }\end{array}$ & $\begin{array}{c}\text { Babies without } \\
\text { Hyperbilirubinaemia } \\
\text { (n = 600) }\end{array}$ & $\begin{array}{c}\text { Babies with } \\
\text { Hyperbilirubinaemia } \\
\text { (n = 100) }\end{array}$ \\
\hline $\begin{array}{c}\text { OA } \\
\text { Incompatibility }\end{array}$ & $112(18.67 \%)$ & $20(20.00 \%)$ \\
\hline $\begin{array}{c}\text { OB } \\
\text { Incompatibility }\end{array}$ & $192(32.00 \%)$ & $23(23.00 \%)$ \\
\hline $\begin{array}{c}\text { Rh } \\
\text { Incompatibility }\end{array}$ & $14(2.33 \%)$ & $25(25.00 \%)$ \\
\hline $\begin{array}{c}\text { No blood group } \\
\text { Incompatibility }\end{array}$ & $282(47.00 \%)$ & $32(32.00 \%)$ \\
\hline \multicolumn{2}{|c|}{ Table 3. Occurrence of Hyperbilirubinaemia } \\
in Relation to Blood Group Incompatibility
\end{tabular}

\begin{tabular}{|c|c|c|}
\hline $\begin{array}{c}\text { Blood Group } \\
\text { Incompatibility }\end{array}$ & $\begin{array}{c}\text { Babies without } \\
\text { Hyperbilirubinaemia } \\
\text { (n= 600) }\end{array}$ & $\begin{array}{c}\text { Babies with } \\
\text { Hyperbilirubinaemia } \\
\text { (n= 100) }\end{array}$ \\
\hline $\begin{array}{c}\mathrm{Rh} \\
\text { Incompatibility }\end{array}$ & $14(2.33 \%)$ & $25(25.00 \%)$ \\
\hline $\begin{array}{c}\text { No Rh } \\
\text { Incompatibility }\end{array}$ & $586(97.67 \%)$ & $75(75.00 \%)$ \\
\hline $\begin{array}{r}\text { Table 4. Tables Considering Individual } \\
\text { Blood Group Incompatibilities }\end{array}$ \\
\hline
\end{tabular}

\begin{tabular}{|c|c|c|}
\hline $\begin{array}{c}\text { Maternal } \\
\text { Disease }\end{array}$ & $\begin{array}{c}\text { Babies without } \\
\text { Hyperbilirubinaemia } \\
\text { (n= 600) }\end{array}$ & $\begin{array}{c}\text { Babies with } \\
\text { Hyperbilirubinaemia } \\
\text { (n = 100) }\end{array}$ \\
\hline GDM & $93(15.50 \%)$ & $14(14.00 \%)$ \\
\hline Hypertension & $60(10.00 \%)$ & $11(11.00 \%)$ \\
\hline Hypothyroidism & $17(2.83 \%)$ & $3(3.00 \%)$ \\
\hline None & $430(71.67 \%)$ & $72(72.00 \%)$ \\
\hline \multicolumn{2}{|c|}{ Table 5. Occurrence of Hyperbilirubinaemia } \\
in Relation to Maternal Disease
\end{tabular}




\begin{tabular}{|c|c|c|}
\hline $\begin{array}{c}\text { Type of } \\
\text { Feeding }\end{array}$ & $\begin{array}{c}\text { Babies without } \\
\text { Hyperbilirubinaemia } \\
(\mathrm{n}=600)\end{array}$ & $\begin{array}{c}\text { Babies with } \\
\text { Hyperbilirubinaemia } \\
(\mathrm{n}=100)\end{array}$ \\
\hline $\begin{array}{c}\text { Exclusively } \\
\text { breast fed }\end{array}$ & $570(95.00 \%)$ & $98(98.00 \%)$ \\
\hline Formula fed & $30(5.00 \%)$ & $2(2.00 \%)$ \\
\hline \multicolumn{2}{|c|}{ Table 6. Occurrence of Hyperbilirubinaemia } \\
in Relation to Type of Feeding
\end{tabular}

\section{DISCUSSION}

In India, incidence of $\mathrm{NNH}$ varied from $4.3 \%$ to $6.5 \%$ of all live born babies.6,7,8 Recently, incidence of significant hyperbilirubinaemia is documented as $10.5 \%$ in term live born babies and $25.3 \%$ in near term group. ${ }^{9}$

Incidence of NNH is $16.67 \%$ of all live born babies in our hospital, which has an annual delivery rate of approx. 4000.

Premature babies have much higher incidence of neonatal jaundice requiring therapeutic intervention than term newborn.10 Neonates with untreated, severe hyperbilirubinaemia (defined as serum total bilirubin level > $20 \mathrm{mg} / \mathrm{dL}$ ) can develop signs of acute bilirubin encephalopathy. If not treated immediately, they might go on to develop kernicterus, a chronic neurologically devastating condition resulting from bilirubin toxicity.

We have noted that the incidence of jaundice of the cases of OA incompatibility, where the mother is of 'O' blood group and the baby is of ' $A$ ' blood group, the percentage of babies who develop hyperbilirubinaemia is $20 \%$. Of the cases of OB incompatibility, where the mother is of ' 0 ' blood group and the baby is of ' $\mathrm{B}$ ' blood group, the percentage of babies who develop hyperbilirubinaemia is $23 \%$. If we take $A B O$ incompatibility together, the incidence of hyperbilirubinaemia is $7.17 \%$.

It is always our temptation to suspect more incidence of neonatal jaundice if mother is ' $\mathrm{O}$ ' and baby is either ' $\mathrm{A}$ ' or ' $\mathrm{B}$.' It is interesting that the studies carried out in different institutions, one in early $60^{\prime} \mathrm{s}^{11}$ and the other in early $70^{\prime} \mathrm{s}^{12}$ have shown that $\mathrm{OA}, \mathrm{OB}$ and total $\mathrm{ABO}$ incompatibility in mother and baby pairs had higher incidence of $\mathrm{NNH}$ and according to those studies a baby with ABO incompatibility had 1.75 times more incidence of jaundice than other mothers and child combination (except Rh incompatibility). Though blood group incompatibility as a group is more significantly associated with NNH in the present study, it is mostly due to incompatibility of $\mathrm{Rh}$ group causing jaundice. $\mathrm{Rh}$ incompatibility in late 80 's was $9.8 \%{ }^{13}$ In our series $\mathrm{Rh}$ incompatibility was $4.16 \%$; it is comparable to the incidence of $\mathrm{Rh}$ incompatibility carried out in different institutions. ${ }^{11}$ The incidence of $\mathrm{NNH}$ in $\mathrm{Rh}$ incompatibility can only be decreased by the religious use of anti-D gamma globulin (Rho GAM) in all deliveries and miscarriages in the Rh negative mothers. In the previous study ${ }^{12}$ from different hospital, the non-ABO, non-Rh group played a significant contribution towards causing jaundice. In the present study, in $32 \%$ of cases of NNH there was no $\mathrm{ABO}$ or Rh incompatibility and we could not correlate other confounding factors. Therefore, maternal blood group other than $\mathrm{Rh}$ negative cannot give us sufficient signal that jaundice will occur in their babies or not.

Though maternal age,14,15 parity,14 use of OCP at the time of conception ${ }^{16,17}$ and maternal disease ${ }^{14,18}$ played a predictive role in causation of $\mathrm{NNH}$ in certain studies, the present study does not show any statistically significant evidence that these factors may play a role in NNH. Malnourished mother and mothers from poorer background with lower per capita income may be at higher risk hyperbilirubinaemia. However, the present study has conclusively proved that there is no statistically significant association of per capita income and nutritional status of mother with $\mathrm{NNH}$ and maternal malnutrition may be blamed for IUGR, but cannot be blamed for higher incidence of $\mathrm{NNH}$.

\section{CONCLUSIONS}

All the maternal factors included in this study could not clearly predict the incidence of $\mathrm{NNH}$, which continues to be a problem towards early discharge of normal new-born babies.

Blood group incompatibility as a whole is associated with increased incidence of hyperbilirubinaemia. ABO incompatibility does not have a significant impact on the incidence of $\mathrm{NNH}$. Rh incompatibility is associated with increased incidence of neonatal hyperbilirubinaemia. Judicious use of inj. Anti-D immunoglobulins should be emphasised in suspected cases of $\mathrm{Rh}$ incompatibility to prevent NNH and its neurological effects.

Early detection of maternal risk factors also should be done to prevent the development of $\mathrm{NNH}$ and kernicterus.

Maternal age, mode of delivery, parity of mother, use of OCP at the time of conception, maternal disease, nutritional status of mother, type of feeding of new-born - all these factors do not have any association with neonatal hyperbilirubinaemia.

\section{Limitation of the Study}

In our hospital, we get middle class and lower middle class pregnant women. So, it is not surprising that there would not be any significant alteration in incidence of jaundice among the above variable.

\section{Scope for Further Research}

If this study could be done in a hospital where people from all status of society, of all nutritional status and all per capita income avail the resources, then it would be a good indicator to point out whether poverty or maternal malnutrition could be a factor in the incidence of $\mathrm{NNH}$.

\section{REFERENCES}

1. Singh B, Ezhilarasan R, Kumar $P$, et al. Neonatal hyperbilirubinemia and its association with thyroid hormone levels and urinary iodine excretion. Indian journal of Pediatrics 2003;70(4):311-5.

2. Kramer LI. Advancement of dermal icterus in the jaundiced newborn. Amer J Dis Child 1969;118(3):454-8.

3. Maisels MJ. Jaundice in neonatology pathophysiology and management of the newborn. In: Avery GB, Flecher MA, MacDonald MG. $4^{\text {th }}$ edn. Lippincot Wiliams and Wilkins 1999:630-725.

4. Hardy JB, Drage JS, Jackson EC. The first year of life: Johns hopkins university press, Baltimore 1979:8-9.

5. American Academy of Pediatrics. Practice parameter: management of hyperbilirubinemia in the healthy term newborn. American academy of pediatrics. Provisional committee for quality improvement and subcommittee on hyperbilirubinemia. Pediatrics 1994;94(4 Pt 1):558-65. 


\section{Jemds.com}

6. Neonatal morbidity and mortality: report of the national neonatal-perinatal database. Indian Pediatrics 1997;34(11):1039-42.

7. Singhal PK, Singh M, Paul VK, et al. Spectrum of neonatal hyperbilirubinemia: an analysis of 454 cases. Indian Pediatrics 1992;29(3):319-25.

8. Narang A, Gathwala G, Kumar P. Neonatal jaundice: an analysis of 551 cases. Indian Pediatrics 1997;34(5):42932.

9. Sarici SU, Serdar MA, Korkmaz A, et al. Incidence, course, and prediction of hyperbilirubinemia in near-term and term newborns. Pediatrics 2004;113(4):775-80.

10. Bhutani VK, Vilms RJ, Hamerman-Johnson L. Universal bilirubin screening for severe neonatal hyperbilirubinemia. J Perinatal 2010;30(Suppl):S6-15.

11. Banerjee AR, Chatterjee D, Roy SK. A preliminary note on mother-child combination of $\mathrm{ABO}$ and $\mathrm{RH}$ blood groups from Calcutta. J Indian Pediatrics 50c 1963;2:13.

12. Ghosal SP, Dutta N, Chatterjee D. Incidence of hyperbilirubinemia in the newborn. Indian Pediatrics 1975;12:317-24.

\section{Original Research Article}

13. Verma M, Chhatwal J, Singh D. Neonatal hyperbilirubinemia. Indian Journal of Pediatrics 1988;55(6):899-904.

14. Linn S, Stiphen CS, Monson RR, et al. Epidemiology of neonatal hyperbilirubinemia. Pediatrics 1985;75(4):7704.

15. Srivastav N, Pande US, Malik GK, et al. A study of serum bilirubin in neonates in relation to the maternal age. Indian journal of medical sciences 1999;53(4):158-61.

16. Wong YK, Wood BSB. Breast milk jaundice and oral contraceptives. British Medical Journal 1971;4(5784): 403-4.

17. McConnell JB, Glasgow JFT, McNai R. Effect on neonatal jaundice of oestrogen and progestogens taken before and after conception. British Medical Journal 1973;3:605-7.

18. Maisels MJ, Gifford K, Antle CE, et al. Jaundice in the healthy newborn infant: a new approach to an old problem. Pediatrics 1988;81(4):505-11. 